\title{
Öğretmenlerin Okul İklimi Algılarının Yordayıcısı Olarak Okul Yöneticilerinin Toksik Liderlik Davranışlari ${ }^{1}$
}

DOI: $10.26466 /$ opus.667320

\author{
Nagihan Tepe ${ }^{*}$ - Gülsşen Yılmaz ** \\ *1Dr. Öğr. Üyesi, Samsun Üniversitesi, İktisadi, İdari ve Sosyal Bilimler Fakültesi, Samsun/Türkiye \\ E-Posta: nagihan.tepe@samsun.edu.tr \\ ORCID: 0000-0002-5923-435X \\ **Dr, Novi Pazar Devlet Üniversitesi, İngiliz Dili ve Edebiyatı Bölümü, Novi Pazar/Sırbistan \\ E-Posta: gulsendanaci7@gmail.com \\ ORCID: 0000-0002-8505-0714
}

\section{Öz}

$\mathrm{Bu}$ araştırmanın amacı öğretmenlerin algılarına göre okul yöneticilerinin toksik liderlik davranışları ile okul iklimi arasındaki ilişkiyi inceleyerek; öğretmenlerin okul iklimi algılarında okul yöneticilerinin toksik liderlik davranışlarının etkisini belirlemektir. İlişkisel tarama modeli ile yürütülen çalışma kapsamında 245 ögrretmen üzerinden elde edilen veriler kullanılmıştır. Araştırma bulgularına göre öğretmenlerin okul iklimi algllarının iyi düzeyde olduğu, okul yöneticilerinin toksik liderlik davranışlarının ise ortalamanın altında olduğu; ayrıca okul iklimi ve alt boyutlarn ile toksik liderlik ve alt boyutlar arasında genelde negatif yönde, anlamlı ve orta düzeyde ilişkiler olduğu tespit edilmiştir. Araştırmanın bir diğer sonucuna göre okul ikliminin \%44'ünün toksik liderliğin alt boyutları tarafından açıklandığı belirlenmiştir. Okul ikliminin toksik liderliğin alt boyutlarına göre yordanmasına ilişkin sonuçlar incelendiğinde olumsuz ruhsal durumun okul iklimi üzerinde anlamlı bir yordayıcı olduğu tespit edilmiştir. Okul iklimin alt boyutu olan demokratiklik ve okula adanma üzerinde olumsuz ruhsal durumun; liderlik ve etkileşim üzerinde ise olumsuz ruhsal durum ve çıkarcılığın anlaml birer yordayıcı olduğu sonucuna ulaşılmıştır.

Anahtar Kelimeler: Toksik Liderlik, Liderlik, Okul İklimi, Öğretmen, Okul Yöneticisi

\footnotetext{
${ }^{1}$ Bu makale "Ondokuz Mayıs Üniversitesi Uluslararası 100.Yıl Eğitim Sempozyumu"nda sunulan "Öğretmenlerin Algılarına Göre Okul iklimi ile Okul Yöneticilerinin Toksik Liderlik Davranışları Arasındaki Ilişskinin Çeşitli Değişkenler Açısından incelenmesi” adlı bildiri genişletilerek hazırlanmıştır.
} 


\title{
Toxic Leadership Behaviours of School Administrators As Predictor Of Teachers' School Climate Perceptions
}

\begin{abstract}
The aim of this study is to determine the effect of toxic leadership behaviors of school administrators' on teachers' perception of school climate by examining the relationship between school leadership and toxic leadership behaviours of school administrators according to teachers' perceptions. The data obtained from 245 teachers were used in the study conducted with relational survey model. According to the findings of the study, teachers' perceptions of school climate were good and school administrators' toxic leadership behaviors were below mean; in addition, negative, significant and medium relationships were found between school climate and its sub-dimensions and toxic leadership and its subdimensions. According to study results, $44 \%$ of the school climate was explained by the subdimensions of toxic leadership. When the results of the estimation of school climate according to the sub-dimensions of toxic leadership were examined, it was found that the negative mood was a significant predictor of school climate. It was concluded that the negative mental state predicts democratism and the dedication to school which is the sub-dimension of the school climate, while negative mental state and self-interestness predicts leadership and interaction.
\end{abstract}

Keywords: Toxic Leadership, School Climate, Teacher, School Administrator 


\section{Giriş}

Okul iklimi konusu son yıllarda eğitim alanındaki araştırmacıların ilgisini çekmektedir. Okul iklimine giderek artan bu ilginin sebebi okul ikliminin olumlu ya da olumsuz oluşunun eğitim ve öğretim faaliyetlerine muhtemel etkisi olabilir. Okul iklimini etkileyen çeşitli faktörler olduğu öne sürülmektedir. Bu faktörlerin ne olduğuna değinmeden önce okul ikliminin ne olduğunu tanımlamak gerekmektedir. Fiziksel olarak birbirine benzese de sosyal oluşum açısından düşünüldüğünde her okulun kendine özgü bir kişiliğinin olması örgüt iklimi ya da okul iklimi kavramları ile ifade edilebilir (Şişman ve Turan, 2005). Okul iklimi, öğretmenlerin okulun genel çalışma çevresiyle ilgili algılamaların, formal örgüt, informal örgüt, üyelerin kişilikleri ve bunları etkileyen örgütsel liderliği kapsayan geniş bir terimdir ancak özetle, bir okulu diğerinden ayıran ve okulun her bir üyesinin davranışını etkileyen okul içi çevreyle ilgili nitelikler olarak tanımlanabilir (Hoy ve Miskel, 2012). Okul ikliminin alt boyutların "demokratiklik ve okula adanma", "liderlik ve etkileşim", "başarı etkenleri", "samimiyet" ve "çatışma" olarak incelemek mümkündür (Canll, Demirtaş ve Özer, 2018).

Olumlu bir okul iklimi çalışanların performansını ve moralini yükseltirken öğrenci başarısını da arttırmaktadır (Freiberg, 1998). Okullardan beklenen temel işlevlerden biri olan etkili öğrenmenin gerçekleştirilmesi için öncelikle okulda olumlu bir öğrenme ve okul ikliminin oluşturulması gerekir ki bu noktada temel belirleyicilerden biri ise okul müdürüdür (Şişman ve Turan, 2005, s. 141). Okuldaki en önemli ve etkili birey olan okul müdürünün liderlik davranışlarının okul ikliminin şekillenmesinde etkili olduğu söylenebilir (Hoy ve Miskel, 2012; Korkmaz, 2007; Kelly, Thornton ve Daugherty, 2005; Şentürk ve Sağnak, 2012).

Liderlerin örgütlerini nasıl geliştirdikleri ve takipçilerinin etkililiğini nasıl artırdıkları eğitimcilerin odaklandığı konuların başında gelir (Pelletier, 2010; Lipman-Blumen, 2011). Okul iklimini etkilemek için gücü, yetkisi ve pozisyonu olan okul müdürü yetenekli ise; güven duygusu, açık iletişim, birliktelik ve etkili geri dönüşüm mekanizmalarını geliştirebilirken diğer taraftan eğer okul müdürleri okulları hakkındaki kritik bilgilere kör iseler, kötü kararlar verebilirler (Kelly, Thornton ve Daugherty, 2005). Dolayssiyla okul müdürlerinin ortaya koydukları liderlik davranışları ve tarzlarının okul iklimi hem olumlu hem olumsuz etkileyebildikleri söylenebilir. 
Okul yöneticilerinin farklı liderlik davranışlarının okul iklimini değiştirdiğine ilişkin çeşitli araştırmalara (Amedome, 2018; Black, 2010; Dinham, 1995; Korkmaz, 2007, Hughes ve Pickeral, 201; Şentürk ve Sağnak, 2012;) rastlamak mümkündür. Korkmaz (2007) dönüşümsel liderliğin örgüt sağllğ1 ve dolayısıyla örgüt iklimi üzerinde olumlu etkisi olduğunu saptamıştır. Dönüşümsel liderlik performansı artırdığı gibi ayn zamanda örgütteki insanları ortak bir amaç etrafında toplar ve geleceğe yönlendirir (Owen, Hodgson ve Gazzard, 2011). Diğer yandan, Black (2010), ise yaptığı araştırmada hizmetkar liderlik ile okul iklimi arasında olumlu anlamlı ilişki olduğu sonucuna ulaşmıştır. Yöneticilerin kullandıkları liderlik stilleri, öğretmenlerin ve öğrencilerin tutumların, morallerini, kişilerarası ilişkileri, okul hedeflerine ve amaçlarına ulaşmalarını büyük ölçüde etkilemekte olup; çalışanların olmak istediği vizyonu yaratan liderlik tarzını benimseyen okul müdürleri, öğretmenlerin ve öğrencilerin katılımını, paylaşılan vizyon ve hedefleri ortaya koyar, öğretmenlerden ve öğrencilerden gelen katkı ise olumlu okul ortamının oluşturulmasını sağlar (Amedome, 2018). Hughes ve Pickeral (2013) ise işbirliği içinde çalışan öğrenci ve çalışanların olduğu, dağıtıcı liderliğin sergilendiği bir okulda gücün ve karar verme yetkisinin paylaşılacağını, böylelikle gruptaki herkesin sorumluluğu ve başarıyı paylaşacağını ve bunun da olumlu okul iklimi yaratacağını öne sürmektedir.

Liderliğin olumsuz çıktılarını ortaya koyan Toksik Liderlik konusu da bu bağlamda sıkça tartışılmaktadır (Allum, 2011; Kasalak ve Aksu, 2016; Kırbaç, 2013; O'Neill, 2017; Pelletier, 2010; Pelletier, 2012; Reed, 2004; Reyhanoğlu ve Akın, 2016; Uysal, 2018; Yavaş, 2016; Zagross ve Jamileh, 2016). Bir örgütün içinde çalışanlara olumsuz sonuçlar doğuran ve örgütün genel olarak performansını azaltan, olumsuz özelliklere sahip liderlik biçimi toksik liderlik olarak tanımlanmaktadır (Reyhanoğlu ve Akın, 2016). Toksik liderler örgütteki işleri zorlaştırabilir, çalışanların enerjisini bitirebilir, astlarının akıl sağlığın tehlikeye atabilir, projelerini bozabilir ve kariyerini mahvedebilir (Lubit, 2004). "Yıkıcı", "zorba", "zalim" ve "toksik" (zehirli) olarak adlandırılan (Goldman, 2011) toksik liderlik, diğer olumsuz liderlik davranışlarını (işyerinde zorbalık, kabalık, yıkıcı liderlik gibi) da içermesi nedeniyle bu liderlik türlerini de kapsayan bir tanımdır (Smith ve FredricksLowman, 2019; Yavaş, 2016). Toksik liderliği "değer bilmezlik", "çıarcılık", "bencillik" ve "olumsuz ruhsal durum" alt boyutları ile incelemek mümkündür (Çelebi, Güner ve Yıldız, 2015). 
Toksik liderlikle ilgili sağlık alanında (İzgüden, Eroymak ve Erdem, 2016), politika alanında (Allum, 2011, Herbert, 2011; Heppel, 2011), askeri alanda (Reed, 2004; Gallus, Walsh, Van Driel, Gouge ve Antolic, 2013) ve işletme alanında (Bayrakçı, 2017;Goldman, 2011; Kasalak ve Aksu, 2016) çalışmalar yapılmıştır. Eğitim alanında ise, toksik liderlik ile ilgili ölçek geliştirme (Bektaş ve Erkal, 2015; Çelebi, Güner ve Yıldız, 2015); ilköğretim birinci kademe öğretmenlerinin toksik liderlik algıları (Çelebi, Güner ve Yıldız, 2013); öğretmen algılarına göre okul müdürlerinin toksik liderlik davranışları ile öğretmenlerin örgütsel sinizm tutumları, tükenmişlik düzeyleri, örgütsel bağlllıkları arasındaki ilişkiyi (Çetinkaya ve Ordu, 2018; Demirel, 2015; Kahveci, Bahadır ve Karagül Kandemir, 2019; Yalçınsoy ve Işık, 2018); okul müdürlerinin liderlik davranışları ve okul iklimi arasındaki ilişkiyi (Şentürk ve Sağnak, 2012) inceleyen araştırmalara rastlamak mümkündür. Ancak öğretmenlerin algılarına göre okul iklimi ve okul yöneticilerinin toksik liderlik davranışları arasındaki ilişkiyi inceleyen bir araştırmaya rastlanmamıştır. Bu sebeple alana katkı sağlayacağı düşünülen bu araştırmanın amacı öğretmenlerin algılarına göre okul yöneticilerinin toksik liderlik davranışları ile okul iklimi arasındaki ilişkiyi inceleyerek; öğretmenlerin okul iklimi algılarında okul yöneticilerinin toksik liderlik davranışlarının etkisini belirlemektir. Bu genel amaç çerçevesinde aşağıdaki sorulara cevap aranmıştır:

1. Öğretmenlerin okul yöneticilerinin toksik liderlik davranışlarına yönelik algıları ne düzeydedir?

2. Öğretmenlerin okul iklimine ilişkin algıları ne düzeydedir?

3. Öğretmenlerin okul yöneticilerine yönelik toksik liderlik algıları ile okul iklimi algıları arasında anlamlı bir ilişki var mıdır?

4. Öğretmenlerin okul yöneticilerine yönelik toksik liderlik algıları okul iklimi algılarının (alt boyutları ile birlikte) anlamlı yordayıcıları mıdır?

\section{Yöntem}

\section{Araştırmanın Modeli}

Bu çalışma nicel araştırma yöntemlerinden biri olan ilişkisel tarama modeli ile gerçekleştirilmiştir. İlişkisel tarama modelinde amaç iki veya daha çok değişken arasındaki ilişkinin incelenmesi olup; değişkenler arasındaki ilişki- 
lerin ortaya çıarılmasına, bu değişkenlerin düzeylerinin tespit edilmesine ve bu değişkenlerle ilgili daha üst düzey araştırılmaların yapılmasına yol göstermesi açısından önemli araştırmalar olarak ifade edilebilir (Büyüköztürk, Çakmak, Akgün, Karadeniz ve Demirel, 2012, s.184-185).

\section{Evren ve Örneklem}

Bu araştırmanın evrenini 2018-2019 eğitim-öğretim yılında Samsun ili Canik ilçesinde görev yapan tüm öğretmenler (1276 kişi) oluşturmaktadır. Örneklemi ise uygun örnekleme yöntemiyle belirlenen 300 öğretmen oluşturmaktadır. Okullara 300 ölçek gönderilmiş, bu ölçeklerin 258'i geri dönmüş, eksik ve hatalı bilgiler ayıklandıktan sonra 245 ölçek çalışmaya dahil edilmiştir. Araştırmaya dahil edilen öğretmenlerin 139 'u (\%57) kadın, 106'sı (\%43) erkektir. Yaşları 20-25 arası 12 (\%5), 26-30 arası 25 (\%10), 31-35 arası 21 (\%9), 36-40 arası 56 (\%23), 41-45 arası 55 (\%22), 46-50 arası 46 (\%19), 51 ve üzeri yaş grubunda ise 30 (\%12) öğretmen bulunmaktadır. Öğretmenlerin mesleki kıdemleri 1-5 yıl arası 29 (\%12), 6-10 yıl arası 26 (\%10), 11-15 yıl arası 41 (\%17), 16-20 yıl arası 63 (\%26), 21-25 yıl arası 54 (\%22) ve 26 yıl ve üzeri ise 32 yıl (\%13) şeklinde değişmektedir. Branşlarına göre öğretmenlerin dağılımı okul öncesi öğretmeni 14 (\%6), sınıf öğretmeni 46 (\%19) ve branş öğretmeni 185 (\%75) şeklindedir. Öğretmenlerin 224'ü (\%91) lisans, 21'i (\%9) ise lisansüstü eğitim mezunudur. Daha önce okul yöneticiliği yapan öğretmenlerin sayısı 50 (\%20), yapmayanların sayısı ise 195 (\%80)'tir.

\section{Veri Toplama Araçları}

Araştırma kapsamında öğretmenlerin okul iklimi algılarını belirlemek amacıyla Okul İklimi Ölçeği, öğretmenlerin algılarına göre okul yöneticilerinin toksik liderlik özelliklerini belirlemek amacıyla ise Toksik Liderlik Ölçeği kullanılmıştır.

Toksik Liderlik Ölçeği: Çelebi, Güner ve Yıldız (2015) tarafından geliştirilen Toksik Liderlik Ölçeği bu araştırma kapsamında kullanılmıştır. Ölçek toplam 30 madde olup, 4 alt boyuttan oluşmaktadır. Bu alt boyutlar bencillik, çıkarcılık, değer bilmezlik ve olumsuz ruhsal durum şeklindedir. Ölçek 5'li likert yapısına sahiptir (1: Kesinlikle Katılmıyorum - 5: Kesinlikle Katılıyorum). 
Ölçekten alınabilecek en düşük puan 30, en yüksek puan ise 150 olup, puanların yükselmesi toksik liderlik özelliğinin arttı̆̆ına işaret etmektedir. Çalışma kapsamında ölçeğe uygulanan açımlayıcı faktör analizi sonucunda maddelerin 4 faktör altında toplandığı ve 4 faktörlü yapının açikladığı toplam varyansın ise $\% 80$ olduğu belirlenmiştir. Madde faktör yükleri .66 ile .88 arasında değişmektedir. Güvenirlik analizi sonucunda ise ölçeğin iç tutarlık katsayısı (Cronbach alpha) .98 olarak hesaplanmıştır. Alt boyutlarına göre ise bu değerler; çıkarcılık ve değer bilmezlik boyutlarında .96, bencillik ve olumsuz ruhsal durum boyutlarında ise .94 olarak tespit edilmiştir.

Okul İklimi Ölçeği: Canl, Demirtaş ve Özer (2018) tarafından geliştirilen okul iklimi ölçeği 23 madde olup, bu maddelerden 4'ü ters kodlanmaktadır. 5'li likert yapısına sahip olan ölçek (5: Her Zaman - 1: Hiçbir Zaman); demokratiklik ve okula adanma, liderlik ve etkileşim, samimiyet, çatışma ve başarı etkenleri olmak üzere 5 alt boyuttan oluşmaktadır. Araştırma kapsamında ölçeğe uygulanan açımlayıc faktör analizi sonucunda maddelerin 5 faktör altında toplandığı ve 5 faktörlü yapının açıkladığı toplam varyansın ise \%71 olduğu belirlenmiştir. Madde faktör yükleri .44 ile .89 arasında değişmektedir. Güvenirlik analizi sonucunda ise ölçeğin iç tutarlık katsayısı (Cronbach alpha) .93 olarak hesaplanmıştır. Alt boyutlarına göre ise bu değerler; demokratiklik ve okula adanma boyutunda .86, liderlik ve etkileşim boyutunda .91, samimiyet boyutunda .87 , çatışma boyutunda .89 ve başarı etkenleri boyutunda ise .80 olarak tespit edilmiştir.

\section{Verilerin Analizi}

Araştırma kapsamında elde edilen veriler analiz edilmeden önce veri seti içerisinde uç değer olup olmadığı ve verilerin normalliği KolmogrovSmirnov ve Shapiro-Wilk testleri ile kontrol edilmiştir. Öğretmenlerin alg1larına göre okul iklimi ve okul yöneticilerinin toksik liderlik düzeyleri belirlenmiş, ölçeklerden aldıkları puanlara ilişkin istatistik hesaplamalar yapılmıştır. Araştırmada ayrıca öğretmenlerin okul iklimi algıları ile okul yöneticilerinin toksik liderlik özellikleri arasında anlamlı bir ilişki olup olmadığ1nın belirlenmesi için de Pearson (r) ve Spearman (rho) analizleri yapılmıştır. Analiz sonucu korelasyon katsayılarına göre 0.70-1.00 arası yüksek, 0.700.30 arası orta, 0.30-0.00 arası değerler ise düşük düzeyde ilişki olarak ifade 
edilmiştir (Büyüköztürk, 2010, s.32). Son olarak öğretmenlerin algilarına göre okul yöneticilerinin toksik liderlik özelliklerinin okul iklimini alt boyutları ile yordayıp yordamadığını test etmek için Çoklu Doğrusal Regresyon Analizi yapılmıştır.

\section{Bulgular}

Öğretmenlerin görüşlerine göre okul iklimi algıları ile okul yöneticilerinin toksik liderlik davranışlarına yönelik algıları alt boyutları ile birlikte Tablo 1 'de gösterilmektedir. Tablo 1 incelendiğinde öğretmenlerin okul iklimi algilarının iyi düzeyde olduğu (= 3.95), öğretmenlerin algılarına göre ise okul yöneticilerinin toksik liderlik davranışlarının ise ortalamanın altında (= 2.06) olduğu belirlenmiştir. Başka bir ifadeyle uygulamanın yapıldığı okullarda okul ikliminin öğretmenlerin görüşlerine göre iyi düzeyde olduğu söylenebilir. Okul yöneticilerinin toksik liderlik davranışların ise çok az gösterdiği ifade edilebilir.

Tablo 1. Öğretmenlerin Algılarna Göre Okul İklimi ile Okul Yöneticilerinin Toksik Liderlik Davranışları

\begin{tabular}{llll}
\hline Değişkenler & $\mathbf{N}$ & $\overline{\mathrm{X}}$ & $\mathrm{S}$ \\
\hline Okul İklimi & 245 & 3.95 & .59 \\
\hline Demokratiklik ve Okula Adanma & 245 & 4.07 & .62 \\
Liderlik ve Etkileşim & 245 & 4.07 & .80 \\
Samimiyet & 245 & 3.80 & .79 \\
Çatışma & 245 & 3.58 & .99 \\
Başarı Etkenleri & 245 & 4.06 & .58 \\
\hline Toksik Liderlik & 245 & 2.06 & .95 \\
\hline Bencillik & 245 & 2.08 & 1.08 \\
Çıkarcilı & 245 & 2.03 & 1.01 \\
Değer Bilmezlik & 245 & 1.94 & .93 \\
Olumsuz Ruhsal Durum & 245 & 2.35 & 1.09 \\
\hline
\end{tabular}

Okul ikliminin alt boyutlarından en yüksek düzeyde olanı öğretmenlerin görüşlerine göre demokratiklik ve okula adanma $(=4.07)$ ile liderlik ve etkileşim $(=$ 4.07) boyutları olduğu görülmektedir. En düşük düzeyde algılanan boyut ise çatışma $(=3.80)$ boyutu olarak ifade edilmiştir. Okul ikliminin iyi düzeyde olduğu düşünüldüğünde çatışma boyutunun en düşük boyut olarak algilanması normal olarak ifade edilebilir. Öğretmenlerin okul yöneticilerinin toksik liderlik davranışlarında algıladıkları en yüksek boyut ise olum- 
suz ruhsal durum olarak $(=2.35)$ belirlenmiştir. Diğer bir anlatımla okul yöneticilerinin olumsuz ruhsal duruma sahip davranışları daha çok sergiledikleri söylenebilir. Değer bilmezlik boyutu $(=1.94)$ ise en az görünen toksik liderlik davranışı olarak ifade edilmiştir. Öğretmenlerin, okul yöneticilerinin değer bilmez davranışlar göstermediğini aksine kendilerine değer verdiğini düşündükleri söylenebilir.

Aşağıda Tablo 2' de öğretmenlerin algılarına göre okul iklimi ile okul yöneticilerinin toksik liderlik davranışları arasındaki ilişkiler gösterilmiştir.

Tablo 2. Öğretmenlerin Algılarnna Göre Okul İklimi ile Okul Yöneticilerinin Toksik Liderlik Davranışlan Arasındaki İlişkiler

\begin{tabular}{|c|c|c|c|c|c|c|c|c|c|c|c|}
\hline & 1 & 2 & 3 & 4 & 5 & 6 & 7 & 8 & 9 & 10 & 11 \\
\hline Okul İklimi & 1.00 & $.87^{* 4}$ & $.86^{* \prime}$ & $.78^{*+}$ & $.71^{* *+}$ & $.66^{* *}$ & $-.65^{*+4}$ & $-.62^{* *}$ & $-.63^{* *}$ & $-.56^{* *}$ & $-.64^{* *}$ \\
\hline Dem. ve O.A. & & 1.00 & $.71^{*}$ & $.70^{*+}$ & $.60^{*+*}$ & $.41^{* *}$ & $-.58^{* *}$ & $-.54^{* *}$ & $-.56^{* *}$ & $-.53^{* *}$ & $-.56^{* *}$ \\
\hline Liderlikve Etk. & & & 1.00 & $.63^{* *}$ & $.50^{* *}$ & $.39^{* *}$ & $-.70^{* *}$ & $-.69^{* *}$ & $-.67^{* *}$ & $-.60^{* *}$ & $-.68^{* *}$ \\
\hline Başarı Etk. & & & & 1.00 & $.55^{* *}$ & $.31^{* *}$ & $-.52^{* *}$ & $-.48^{* *}$ & $-.46^{* *}$ & $-.48^{* *}$ & $-.56^{* *}$ \\
\hline Samimiyet & & & & & 1.00 & $.35^{* *}$ & $.41^{* *}$ & $.39^{* *}$ & $.42^{* *}$ & $.33^{* *}$ & $.41^{* *}$ \\
\hline Çatışma & & & & & & 1.00 & .27 & $.25^{* *}$ & $.28^{* *}$ & $.22^{*+}$ & $.25^{* *}$ \\
\hline Toksik L. & & & & & & & 1.00 & $.96 *$ & $.96^{* *}$ & $.90^{* *}$ & $.91^{* *}$ \\
\hline Çıkarcılık & & & & & & & & 1.00 & $.91^{* *}$ & $.87^{\prime \prime}$ & $.86^{* *}$ \\
\hline Değer Bilmz. & & & & & & & & & 1.00 & $.86^{* *}$ & $.84^{* *}$ \\
\hline Bencillik & & & & & & & & & & 1.00 & $.78^{* *}$ \\
\hline Olumsuz R.D. & & & & & & & & & & & 1.00 \\
\hline
\end{tabular}

$" p<01$

Öğretmenlerin algılarına göre okul iklimi ile okul yöneticilerinin toksik liderlik davranışları arasındaki ilişkilere yönelik Tablo 2 incelendiğinde okul iklimi ve alt boyutları ile toksik liderlik ve alt boyutları arasında genelde negatif yönde, anlamlı ve orta düzeyde ilişkiler olduğu görülmektedir. Diğer bir anlatımla okul yöneticilerinin toksik liderlik davranışları azaldıkça öğretmenlerin okul iklimine ilişkin görüşler olumlu yönde artmaktadır. En düşük düzeyde ilişkiler okul iklimin alt boyutu olan çatışma boyutu ile toksik liderlik ve alt boyutları arasında görülmektedir. En yüksek düzeyde ilişkiler ise okul iklimin alt boyutu olan liderlik ve etkileşim ile toksik liderlik arasında görülmektedir. Başka bir anlatımla okul yöneticilerinin toksik liderlik davranışları artıkça okuldaki çatışma ortamı da artmaktadır. Okul yöneticilerinin toksik liderlik davranışları azaldığında ise okul ikliminde liderlik ve etkileşim artmaktadır. Yöneticilerinin yıpratıcı ve zararlı davranışlarına maruz kalan öğretmenler hem yöneticileri ile hem de meslektaşları 
arasında çatışma ortamına maruz kalabilir. Okul ikliminde liderlik ve etkileşim iklimin yaşanması da yöneticinin yıpratıcı ve zararlı davranışlar göstermediği anlamına gelebilir.

Okul ikliminin toksik liderliğin alt boyutlarına göre yordanmasına ilişkin çoklu doğrusal regresyon analizi sonuçları aşağıda Tablo 3'te verilmiştir.

Tablo 3. Okul İkliminin Toksik Liderliğin Alt Boyutlarnna Göre Yordanmasına İlişkin Çoklu Doğrusal Regresyon Analizi Sonuçlarn

\begin{tabular}{llllll} 
Değişken & $\boldsymbol{B}$ & Standart Hata B & $\boldsymbol{\beta}$ & $\boldsymbol{t}$ & $\boldsymbol{p}$ \\
\hline Sabit & 4.81 & .06 & - & 69.4 & .00 \\
Çıarcllık & .07 & .78 & .12 & .95 & .33 \\
Değer Bilmezlik & .12 & .08 & .20 & 1.58 & .11 \\
Bencillik & .40 & .05 & .02 & .22 & .82 \\
Olumsuz Ruhsal Durum & .16 & .05 & .34 & 3.42 & .00 \\
\hline
\end{tabular}

$F=47.132 p=.00 R=.66 R^{2}=.44$

Regresyon analizi sonuçlarına göre okul ikliminin yordanmasına ilişkin regresyon eşitliği şu şekildedir:

Okul İklimi $=4.81+.07^{*}$ Çıkarcllık $+.12^{*}$ Değer Bilmezlik $+.40^{*}$ Bencillik + $.16^{*}$ Olumsuz Ruhsal Durum

Tablo 3'teki verilere göre, öğretmenlerin okul iklimi algılarının toksik liderliğin alt boyutları ile orta düzeyde ve anlamlı bir ilişki vermekte olduğu görülmektedir $(R=.66, p<.05)$. Bu yordayıcı değişkenler, okul iklimine ait varyansın \%44'ünü açıklamaktadır. Standardize edilmiş regresyon katsayılarına göre, okul iklimi üzerindeki göreli önem sıraları; olumsuz ruhsal du$\operatorname{rum}(\beta=.34)$, değer bilmezlik $(\beta=.20)$, çıarcılık $(\beta=.12)$, ve bencillik $(\beta=$ .02) şeklindedir. Regresyon katsayılarının anlamlılığına ilişkin t-testi sonuçları incelendiğinde ise, olumsuz ruhsal durumun $(t=3.42, p<.05)$ okul iklimi üzerinde anlamlı bir yordayıcı olduğu görülmektedir. Diğer alt boyutlar ise anlamlı birer yordayıcı değildir.

Aşağıda Tablo 4'te demokratiklik ve okula adanmanın toksik liderliğin alt boyutlarına göre yordanmasına ilişkin çoklu doğrusal regresyon analizi sonuçlarına yer verilmiştir. 
Öğretmenlerin Okul İklimi Algılarının Yordayıcısı Olarak Okul Yöneticilerinin Toksik Liderlik Davranışları

Tablo 4. Demokratiklik ve Okula Adanmanın Toksik Liderliğin Alt Boyutlarna Göre Yordanmasına İlişkin Çoklu Doğrusal Regresyon Analizi Sonuçlarn

\begin{tabular}{llllll}
\hline Değişken & $\boldsymbol{B}$ & Standart HataB & $\boldsymbol{\beta}$ & $\boldsymbol{t}$ & $\boldsymbol{p}$ \\
\hline Sabit & 4.88 & .07 & - & 62.2 & .00 \\
Çıarcllk & .03 & .08 & .06 & .42 & .67 \\
Değer Bilmezlik & .13 & .09 & .20 & 1.51 & .13 \\
Bencillik & .10 & .06 & .18 & 1.77 & .07 \\
Olumsuz Ruhsal Durum & .16 & .06 & .29 & 2.75 & .00 \\
\hline
\end{tabular}

$F=32.561 p=.00 R=.59 R^{2}=.35$

Regresyon analizi sonuçlarına göre Demokratiklik ve Okula Adanmanın yordanmasına ilişkin regresyon eşitliği şu şekildedir:

Demokratiklik ve Okula Adanma $=4.88+.03^{*}$ Çıkarcılık $+.13^{*}$ Değer Bilmezlik $+.10^{*}$ Bencillik $+.16^{*}$ Olumsuz Ruhsal Durum

Tablo 4 incelendiğinde, öğretmenlerin demokratiklik ve okula adanma algilarının toksik liderliğin alt boyutlanı ile orta düzeyde ve anlamlı bir ilişki vermekte olduğu görülmektedir $(R=.59, p<.05)$. Bu yordayıcı değişkenler, demokratiklik ve okula adanmaya ait varyansın \%35'ini açıklamaktadır. Standardize edilmiş regresyon katsayılarına göre, demokratiklik ve okula adanma üzerindeki göreli önem sıraları; olumsuz ruhsal durum $(\beta=.16)$, değer bilmezlik $(\beta=.13)$, bencillik $(\beta=.10)$ ve çıarcllık $(\beta=.03)$ şeklindedir. Regresyon katsayılarının anlamlılığına ilişkin t-testi sonuçları incelendiğinde ise, olumsuz ruhsal durumun $(t=2.75, p<.05)$ demokratiklik ve okula adanma üzerinde anlamlı bir yordayıcı olduğu görülmektedir. Diğer alt boyutlar ise anlamlı birer yordayıcı değildir.

Tablo 5'te liderlik ve etkileşimin toksik liderliğin alt boyutlarına göre yordanmasına ilişkin çoklu doğrusal regresyon analizi sonuçları gösterilmiştir.

Tablo 5. Liderlik ve Etkileşimin Toksik Liderliğin Alt Boyutlarna Göre Yordanmasına İlişkin Çoklu Doğrusal Regresyon Analizi Sonuçlan

\begin{tabular}{llllll}
\hline Değişken & $\boldsymbol{B}$ & Standart Hata B & $\boldsymbol{\beta}$ & $\boldsymbol{t}$ & $\boldsymbol{p}$ \\
\hline Sabit & 5.32 & .08 & - & 60.86 & .00 \\
Çıkarcllk & .30 & .09 & .38 & 3.09 & .00 \\
Değer Bilmezlik & .12 & .10 & .13 & 1.17 & .24 \\
Bencillik & .05 & .06 & .07 & .83 & .40 \\
Olumsuz Ruhsal Durum & .21 & .06 & .29 & 3.15 & .00 \\
\hline
\end{tabular}

$F=64.625 p=.00 R=.72 R^{2}=.51$ 
Regresyon analizi sonuçlarına göre Liderlik ve Etkileşimin yordanmasına ilişkin regresyon eşitliği şu şekildedir:

Liderlik ve Etkileşim $=5.32+.30 *$ Çıkarcılık $+.12 *$ Değer Bilmezlik $+.05^{*}$ Bencillik $+.21^{*}$ Olumsuz Ruhsal Durum

Tablo 5'teki verilere göre öğretmenlerin liderlik ve etkileşim algılarının toksik liderliğin alt boyutları ile orta düzeyde ve anlamlı bir ilişki vermekte olduğu görülmektedir $(R=.51, p<.05)$. Bu yordayıcı değişkenler, liderlik ve etkileşime ait varyansın \%51'ini açıklamaktadır. Standardize edilmiş regresyon katsayılarına göre, liderlik ve etkileşim üzerindeki göreli önem sıralarl; çıkarcılık $(\beta=.30)$, olumsuz ruhsal durum $(\beta=.21)$, değer bilmezlik $(\beta=.12)$ ve bencillik $(\beta=.05)$ şeklindedir. Regresyon katsayılarının anlamlılığına ilişkin t-testi sonuçları incelendiğinde ise, olumsuz ruhsal durum $(t=3.15, p$ $<.05)$ ve çıkarclık $(t=3.09, p<.05)$ boyutlarının liderlik ve etkileşim üzerinde anlamlı birer yordayıcı olduğu görülmektedir. Diğer alt boyutlar ise anlamlı birer yordayıcı değildir.

Aşağıda Tablo 6' da başarı etkenlerinin toksik liderliğin alt boyutlarına göre yordanmasına ilişkin çoklu doğrusal regresyon analizi sonuçlarına yer verilmiştir.

Tablo 6. Başarn Etkenlerinin Toksik Liderliğin Alt Boyutlarna Göre Yordanmasına İlişkin Çoklu Doğrusal Regresyon Analizi Sonuçları

\begin{tabular}{llllll}
\hline Değişken & $\boldsymbol{B}$ & Standart HataB & $\boldsymbol{\beta}$ & $\boldsymbol{t}$ & $\boldsymbol{p}$ \\
\hline Sabit & 4.77 & .07 & - & 63.90 & .01 \\
Çıkarcllk & .02 & .08 & .04 & .26 & .78 \\
Değer Bilmezlik & .12 & .08 & .19 & 1.39 & .16 \\
Bencillik & .09 & .05 & .17 & 1.65 & .09 \\
Olumsuz Ruhsal Durum & .29 & .05 & .55 & 5.07 & .00 \\
\hline
\end{tabular}

$F=29.252 p=.00 R=.57 R^{2}=.32$

Regresyon analizi sonuçlarına göre Başarı Etkenlerinin yordanmasına ilişkin regresyon eşitliği şu şekildedir:

Başarı Etkenleri $=4.77+.02^{*}$ Çıkarcılık $+.12 *$ Değer Bilmezlik $+.09 *$ Bencillik $+.29 *$ Olumsuz Ruhsal Durum

Tablo 6 incelendiğinde öğretmenlerin başarı etkenleri algılarının toksik liderliğin alt boyutları ile orta düzeyde ve anlamlı bir ilişki vermekte olduğu görülmektedir $(R=.57, p<.05)$. Bu yordayıcı değişkenler, başarı etkenlerine ait varyansın \%57'sini açılamaktadır. Standardize edilmiş regresyon katsayılarına göre, başarı etkenleri üzerindeki göreli önem sıraları; olumsuz ruh- 
sal durum $(\beta=.29)$, değer bilmezlik $(\beta=.12)$, bencillik $(\beta=.09)$ ve çkarcilık $(\beta=.02)$ şeklindedir. Regresyon katsayılarının anlamlılığına ilişkin t-testi sonuçları incelendiğinde ise, olumsuz ruhsal durumun $(t=5.07, p<.05)$ başarı etkenleri üzerinde anlamlı bir yordayıcı olduğu görülmektedir. Diğer alt boyutlar ise anlamlı birer yordayıcı değildir.

Aşağıda Tablo 7'de samimiyetin toksik liderliğin alt boyutlarına göre yordanmasına ilişkin çoklu doğrusal regresyon analizi sonuçları gösterilmiştir.

Tablo 7. Samimiyetin Toksik Liderliğin Alt Boyutlarına Göre Yordanmasına İlişkin Çoklu Doğrusal Regresyon Analizi Sonuçlarn

\begin{tabular}{llllll} 
Değişken & $\boldsymbol{B}$ & Standart HataB & $\boldsymbol{\beta}$ & $\boldsymbol{t}$ & $\boldsymbol{p}$ \\
\hline Sabit & 4.55 & .11 & - & 40.71 & .00 \\
Çıarcilk & .01 & .12 & .02 & .15 & .87 \\
Değer Bilmezlik & .24 & .13 & .28 & 1.85 & .06 \\
Bencillik & .08 & .08 & .11 & .96 & .33 \\
Olumsuz Ruhsal Durum & .17 & .08 & .24 & 2.00 & .04 \\
\hline
\end{tabular}

$F=14.269 p=.00 R=.43 R^{2}=.19$

Tablo 7'deki verilere göre ögrretmenlerin samimiyet algılarının toksik liderliğin alt boyutları ile orta düzeyde ve anlamlı bir ilişki vermekte olduğu görülmektedir $(R=.43, p<.05)$. Bu yordayıcı değişkenler, samimiyete ait varyansın \%19'unu açıklamaktadır. Standardize edilmiş regresyon katsayılarına göre, samimiyet üzerindeki göreli önem sıraları; değer bilmezlik ( $\beta=$ .24), olumsuz ruhsal durum $(\beta=.17)$, bencillik $(\beta=.08)$ ve çıarcilık $(\beta=.01)$ şeklindedir. Regresyon katsayılarının anlamlılığına ilişkin t-testi sonuçları incelendiğinde ise, olumsuz ruhsal durumun $(t=2.00, p<05)$ samimiyet üzerinde anlamlı bir yordayıcı olduğu görülmektedir. Diğer alt boyutlar ise anlamlı birer yordayıcı değildir.

Regresyon analizi sonuçlarına göre Samimiyetin yordanmasına ilişkin regresyon eşitliği şu şekildedir:

Samimiyet $=4.55+.01^{*}$ Çıarcılık $+.24^{*}$ Değer Bilmezlik $+.08^{*}$ Bencillik+.17*Olumsuz Ruhsal Durum

Aşağıda Tablo 8'de çatı̧manın toksik liderliğin alt boyutlarına göre yordanmasına ilişkin çoklu doğrusal regresyon analizi sonuçlarına yer verilmiştir. 
Tablo 8. Çatışmanın Toksik Liderliğin Alt Boyutlarına Göre Yordanmasına İlişkin Çoklu Doğrusal Regresyon Analizi Sonuçlarn

\begin{tabular}{llllll}
\hline Değişken & $\boldsymbol{B}$ & Standart HataB & $\boldsymbol{\beta}$ & $\boldsymbol{t}$ & $\boldsymbol{p}$ \\
\hline Sabit & 4.18 & .14 & - & 28.15 & .00 \\
Çıarcllk & .00 & .16 & .00 & .05 & .96 \\
Değer Bilmezlik & .28 & .17 & .27 & 1.65 & .09 \\
Bencillik & .04 & .11 & .04 & .36 & .71 \\
Olumsuz Ruhsal Durum & .06 & .11 & .06 & .54 & .58 \\
\hline
\end{tabular}

$F=5.36 p=.00 R=.28 R^{2}=.08$

Regresyon analizi sonuçlarına göre Çatışmanın yordanmasına ilişkin regresyon eşitliği şu şekildedir:

Çatışma $=4.18+.00^{*}$ Çıkarcılık $+.28^{*}$ Değer Bilmezlik $+.04^{*}$ Bencillik + $.06 *$ Olumsuz Ruhsal Durum

Tablo 8 incelendiğinde öğretmenlerin çatışma algilarının toksik liderliğin alt boyutları ile düşük düzeyde ve anlamlı bir ilişki vermekte olduğu görülmektedir $(R=.28, p<.05)$. Bu yordayıcı değişkenler, çatışmaya ait varyansın \%08'ini açıklamaktadır. Standardize edilmiş regresyon katsayılarına göre, çatışma üzerindeki göreli önem sıraları; değer bilmezlik $(\beta=.28)$, olumsuz ruhsal durum $(\beta=.06)$, bencillik $(\beta=.04)$ ve çıarcılık $(\beta=.00)$ şeklindedir. Regresyon katsayılarının anlamlılığına ilişkin t-testi sonuçları incelendiğinde ise toksik liderliğin alt boyutlarının tamamının çatışma üzerinde anlamlı birer yordayıcı olmadığı görülmektedir.

\section{Tartışma ve Sonuç}

Araştırma sonuçlarına göre öğretmenlerin okul iklimi algilarının iyi düzeyde olduğu, öğretmenlerin algilarına göre okul yöneticilerinin toksik liderlik davranışlarının ise ortalamanın altında olduğu belirlenmiştir. Literatür incelendiğinde öğretmenlerin algllarına göre okul yöneticilerinin toksik liderlik davranışlarını çok az gösterdiği çeşitli çalışmalara rastlanmışır (Çetinkaya ve Ordu; 2017; Kahveci, Bahadır ve Kandemir, 2019). Bazı çalışmalarda ise yöneticilerin toksik davranışlar sergilediği sonucuna ulaşılmıştır (Bozkurt, Çoban ve Çolakoğlu, 2018; Demirdağ, 2018; Demirel, 2015; Uysal, 2018). "Demokratiklik ve okula adanma" ile "liderlik ve etkileşim" boyutları okul ikliminin alt boyutlarından en yüksek düzeyde olan; "çatışma" boyutu ise en düşük düzeyde algilanan boyutlar olarak tespit edilmiştir. Okul yöneticilerinin toksik liderlik davranışlarında algılanan en yüksek boyut "olumsuz ruhsal durum" olarak; en düşük boyut ise "değer bilmezlik" boyutu olarak 
belirlenmiştir. Bu bulgu Çetinkaya ve Ordu (2018) ve Demirel'in (2015) araştırma bulguları ile paralellik göstermektedir.

Öğretmenlerin okul iklimi ve alt boyutlarına ilişkin algıları ile okul yöneticilerinin toksik liderlik davranışları ve alt boyutları arasındaki ilişki incelendiğinde ise genelde negatif yönde, anlamlı ve orta düzeyde ilişkiler olduğu sonucuna ulaşılmıştır. En düşük düzeyde ilişkiler okul iklimin alt boyutu olan çatışma boyutu ile toksik liderlik ve alt boyutları arasında görülmektedir. En yüksek düzeyde ilişkiler ise okul iklimin alt boyutu olan liderlik ve etkileşim ile toksik liderlik ve etkileşim arasında görülmektedir. Bu sonuçlar Şentürk ve Sağnak (2012); Eroğluer ve Yılmaz (2015); Freiberg (1998); Kelly, Thornton ve Daugherty'nin (2005) okul yöneticilerinin liderlik davranışının okul iklimini etkilediği bulguları ile desteklenmektedir.

Araştırmanın bir diğer sonucuna göre okul ikliminin \%44'ünün toksik liderliğin alt boyutları değer bilmezlik, çıkarcılık, bencillik ve olumsuz ruhsal durum tarafından açılandığı söylenebilir. Okul ikliminin toksik liderliğin alt boyutlarına göre yordanmasına ilişkin sonuçlar incelendiğinde olumsuz ruhsal durumun okul iklimi üzerinde anlamlı bir yordayıcı olduğu tespit edilmiştir. Okul iklimin alt boyutu olan demokratiklik ve okula adanma üzerinde olumsuz ruhsal durumun; liderlik ve etkileşim üzerinde olumsuz ruhsal durum ve çıarcllğın; başarı etkenleri üzerinde olumsuz ruhsal durumun; samimiyet üzerinde olumsuz ruhsal durumun anlamlı birer yordayıcı olduğu sonucuna ulaşılmıştır. Çatışma alt boyutu üzerinde ise toksik liderliğin alt boyutlarının tamamının birer yordayıcı olmadığ belirlenmiştir. Goldman (2011), araştırmanın bu bulguları ile paralel olarak toksik liderlerin işgörenlerin sadakatini, motivasyonunu, sağlı̆̆ını, mutluluğunu ve dolayısıyla iklimi olumsuz etkilediğini belirtmektedir. Benzer şekilde Kasalak ve Aksu'nun (2016) toksik davranışların işgörenlerde olumsuz duyguların ortaya çıkması ve yinelenmesi şeklinde etki bıraktığı bulgusu ile; Reyhanoğlu ve Akın'ın (2016) toksik liderlik davranışlarının örgütlerde olumsuz bir hava yaratabileceği bulgularının araştırma sonucu ile uyumlu olduğu söylenebilir.

\section{Öneriler}

Okul yöneticileri okul iklimini daha verimli hale getirmeyi temel amaç edinmeli ve okulun niteliğini artırmayı kendi çıkarlarının üzerinde tutmalıdır. Yöneticilerin olumsuz ruhsal durum davranışlarının okul iklimi ve alt 
boyutları arasında anlamlı birer yordayıcı olarak tespit edilmesi çarpıcı bir sonuçtur. Buna göre okul yöneticilerinin seçim şekli ve atanma kriterleri sadece bilimsel yeterlik alanı ile sınırlandırılmamalı, yöneticilerin ruhsal durum açısından da yeterli olması sağlanmalıdır. Bu çalışma sadece öğretmenlerin görüşleri alınarak ve nicel yöntemlerle gerçekleştirilmiştir. Konu hakkında yöneticilerin bakış açısını da öğrenmek için çalışma grubu olarak yöneticilerin belirlendiği, veri toplama yöntemi olarak ise gözlem ve görüşmelerin gerçekleştirildiği araştırmalar yapılabilir. 


\title{
EXTENDED ABSTRACT
}

\section{Toxic Leadership Behaviors of School Administrators As Predictor Of Teachers' School Climate Perceptions}

\author{
Nagihan Tepe - Gülşen Yılmaz \\ Samsun University, Novi Pazar University
}

The subject of school climate has attracted the attention of researchers in the field of education in recent years. The reason for this growing interest in school climate may be the positive or negative impact of school climate on education and training activities. Before mentioning the various factors that affect climate, it is needed to define what school climate is. The fact that each school has its own personality can be expressed with the concepts of organizational climate or school climate (Şişman and Turan, 2005). School climate is a broad term that covers teachers' perceptions about the school's general working environment, formal organization, informal organization, personalities of the members and organizational leadership affecting them, but in summary, it can be defined as qualities in the school environment that separate one school from another and affect the behaviour of each member of the school ( Hoy and Miskel, 2012). It is possible to examine the sub-dimensions of the school climate as "democracy and commitment to school", "leadership and interaction", "factors of success", "sincerity" and "conflict" (Canl, Demirtaş and Özer, 2018).

A positive school climate increases the performance and morale of the employees while increasing student success (Freiberg, 1998). In order to realize effective learning, which is one of the basic functions expected from schools, a positive learning and school climate must be established in school. To realize this function, one of the main determinants is the school principal (Şişman and Turan, 2005, p. 141). It can be said that the leadership behaviour of the school principal, who is the most important and influential individual in the school, is effective in creating the school climate (Hoy and Miskel, 2012; Korkmaz, 2007; Kelly, Thornton and Daugherty, 2005; Şentürk and Sağnak, 2012). How leaders develop their organizations and increase 
the effectiveness of their followers is one of the topics that educators focus on (Pelletier, 2010; Lipman-Blumen, 2011). If the principal, who has the power, authority and position to affect the school climate, is capable, he can develop trust, open communication, cooperation and effective reformation mechanisms, on the other hand, if the principals are blind to critical information about their schools, they can make bad decisions (Kelly, Thornton, and Daugherty, 2005). Therefore, it can be said that the leadership behaviours and styles of school principals can affect the school climate both positively and negatively.

Toxic Leadership, which reveals the negative outcomes of leadership, is also frequently discussed within this context (Allum, 2011; Kasalak and Aksu, 2016; Kırbaç, 2013; O'Neill, 2017; Pelletier, 2010; Pelletier, 2012; Reed, 2004; Reyhanoğlu and Akın, 2016; Uysal, 2018; Yavaş, 2016; Zagross and Jamileh, 2016). Toxic leadership is defined as the leadership type that has negative characteristics and decreases the performance of the organization in general, with negative results (Reyhanoğlu and Akın, 2016). Toxic leadership has a comprehensive definition including the terms "destructive", "bully", "cruel" and "toxic" (poisoned) (Goldman, 2011) and includes other negative leadership behaviours (such as workplace bullying, rudeness, destructive leadership, etc.) (Smith and Fredricks-Lowman, 2019; Slow, 2016). It is possible to examine toxic leadership with the sub-dimensions of "selfinterest", "not appreciating", "selfishness" and "negative mental state" (Çelebi, Güner and Yıldız, 2015).

In different fields, such as health (İzgüden, Eroymak and Erdem, 2016), politics (Allum, 2011, Herbert, 2011; Heppel, 2011), military (Reed, 2004; Gallus, Walsh, Van Driel, Gouge and Antolic, 2013) and organization (Bayrakç1, 2017; Goldman, 2011; Kasalak and Aksu, 2016), toxic leadership has been studied. In the field of education, there are also studies amin to develop a scale related to toxic leadership (Bektaş and Erkal, 2015; Çelebi, Güner and Yıldiz, 2015); examine toxic leadership perceptions of primary school teachers (Çelebi, Güner and Yıldız, 2013); investigate the relationship between the school leaders' toxic leadership behaviours and teachers' organizational cynicism attitudes, burnout levels, and organizational commitment (Çetinkaya and Ordu, 2018; Demirel, 2015; Kahveci, Bahadır and Karagül Kandemir, 2019; Yalçınsoy and Işık, 2018) and the relationship between school principals' leadership behaviour and school climate (Şen- 
türk and Sağnak, 2012). However, it has not been reached a study that examines the relationship between school climate and school leaders' toxic leadership behaviours according to the teachers' perceptions.

Within this scope, aim of this study is to determine the effect of toxic leadership behaviours of school administrators' on teachers' perception of school climate by examining the relationship between school leadership and toxic leadership behaviours of school administrators according to teachers' perceptions. The data obtained from 245 teachers were used in the study conducted with relational survey model. According to the findings of the study, teachers' perceptions of school climate were good and school administrators' toxic leadership behaviours were below mean; in addition, negative, significant and medium relationships were found between school climate and its sub-dimensions and toxic leadership and its sub-dimensions. According to study results, $44 \%$ of the school climate was explained by the sub-dimensions of toxic leadership. When the results of the estimation of school climate according to the sub-dimensions of toxic leadership were examined, it was found that the negative mood was a significant predictor of school climate. It was concluded that the negative mental state predicts democratism and the dedication to school which is the sub-dimension of the school climate, while negative mental state and self-interest predicts leadership and interaction.

\section{Kaynakça / References}

Allum, F. (2011). Silvio Berlusconi and his 'toxic' touch. Representation, 47(3), 281294.

Amedome, S. N. (2018). The influence of leadership on school climate: A case of senior high schools in hohoe municipality of Ghana, Academy of Educational Leadership Journal, 22(2).

Bayrakçı, E. (2017). Zehirli liderlik, Örgütsel zehirlenme ve zehirlenmeyi gidermede ifşa olasılığı üzerine nitel bir araştırma, Route Educational and Social Science Journal, 4(6), 34-56.

Bektaş, M. ve Erkal, P. (2015). Örgütlerde toksisite davranışları: Toksik duygu deneyimleri ölçeğinin geçerlilik ve güvenirliği çalısması. Research Journal of Business and Management, 31(4), 519-529.

Black, G. L. (2010). Correlational analysis of servant Leadership and school climate. Journal of Catholic Education, 13(4), 436-466 . 
Bozkurt, S., Çoban, Ö., ve Çolakoğlu, M. H. (2018). Örgütsel güven düzeyi ve toksik liderlikdavranışları ilişkisinde örgütsel bağlılığın aracı etkisi. Hacettepe Üniversitesi Ĕ̆itim Fakültesi Dergisi.

Büyüköztürk, Ş., Çakmak, E. K, Akgün, Ö. E., Karadeniz, Ş. ve Demirel, F. (2012). Bilimsel araştırma yöntemleri (12. Basım). Ankara: PegemA.

Canlı, S., Demirtaş, H. ve Özer, N. (2018).Okul iklimi ölçeğinin geçerlik ve güvenirlik çalışması. Elementary Education Online, 17(4), 1797-1811

Çelebi, N., Güner, H. ve Yıldız, V. (2015). Toksik liderlik ölçeğinin geliştirilmesi. Bartın Üniversitesi Ĕ̆itim Fakültesi Dergisi, 4(1), 249-268.

Çelebi, N., Güner, H. ve Yıldız, V. (2013). İlköğretim birinci ve ikinci kademe öğretmenlerinin toksik liderlik algıları. Sekizinci Ulusal Eğitim Yönetimi Kongresi. İstanbul: Marmara Üniversitesi. 145-147.

Çetinkaya, H. ve Ordu, A. (2018). Okul yöneticilerinin toksik (zehirli) liderlik davranışları ile öğretmenlerin tükenmişlik düzeyleri arasındaki ilişki. Pamukkale Üniversitesi Sosyal Bilimler Enstitüsü Dergisi, 31, 15-28.

Demirel, N. (2015). Öğretmen algılarnna göre okul müdürlerinin toksik liderlik davranışlar ile öğretmenlerin örgütsel sinizm tutumları arasındaki ilişki: Gaziantep Şehitkâmil ilçesi örneği. Yayımlanmamış yüksek lisans tezi, Kahramanmaraş Sütçü İmam Üniversitesi, Gaziantep.

Demirdağ, S. (2018). The perceptions of academicians on organizational toxicity. Kastamonu Education Journal, 26(4), 1319-1334.

Dinham, S., Cairney, T, Craigie, D. ve Wilson, S. (1995). School climate and leadership: Research into three secondary schools. Journal of Educational Administration, 33(4), 36-58.

Eroğluer, K. ve Yılmaz, Ö. (2015). Etik liderlik davranışlarının algılanan örgüt iklimi üzerine etkisine yönelik bir uygulama: İş yaşamında yalnızlık duygusunun aracilık etkisi. İsletme Araştırmalar Dergisi, 7(1), 280-308.

Freiberg, H. J. (1998). Measuring school climate: Let me count the ways. Educational Leadership, 56(1), 22-26.

Gallus, J. A., Walsh, B. M., Van Driel, M., Gouge, M. C. ve Antolic, E. (2013).Intolerable cruelty: A multilevel examination of the impact of toxic leadership on U.S. military units and service members. Military Psycho$\log y, 26(6), 588-601$.

Goldman, A. (2011). Demagogue to dialogue: An alternative to toxic leadership in corporate downsizings. Organizational Dynamics, 40, 235-241. 
Heppel,T. (2011). Toxic leadership: Applying the Lipman Blumen model to political leadership. Representation, 47(3), 241-249, DOI:10.1080/00344893.2011.596422

Herbert, J. (2011). The toxic presidency of George W. Bush. Representation, 47(3), 265-280, DOI: 10.1080/00344893.2011.596428.

Hoy, W. K. ve Miskel, C. G. (2012). Eğitim yönetimi: Teori ve uygulama(Çev. E. Turan). Ankara: Nobel.

Hughes, W. ve Pickeral, T. (2013). School climate and shared leadership. National School Climate Center (NSCC).

İzgüden, D., Eroymak, S. ve Erdem, R. (2016). Sağlık kurumlarında görülen toksik liderlik davranışları: Bir üniversite hastanesi örneği. Balkan Sosyal Bilimler Dergisi, 262-276.

Kahveci, G, Bahadır, E. ve Karagül Kandemir, İ. (2019).Okul yöneticilerinin toksik liderlik davranışları ile öğretmenlerin örgütsel bağlılıkları arasındaki ilişkinin incelenmesi. Ankara Üniversitesi Ĕ̆itim Bilimleri Fakültesi Dergisi, 52 (1), 225-249.

Kasalak, G. ve Aksu, M. B. (2016). Örgütler nasıl zehirlenir? Öğretim elemanlarının örgütsel toksisite algıları. Hacettepe Üniversitesi Eğitim Fakültesi Dergisi, 31(4), 676-694.

Kelly, R. C., Thornton, B. ve Daugherty, R. (2005). Relationships between measures of leadership and school climate. Education, 126(1), 17-28.

Kırbaç, M. (2013). Ĕ̆itim örgütlerinde toksik liderlik. Yayımlanmamış yüksek lisans tezi, İnönü Üniversitesi, Malatya.

Korkmaz, M. (2007). Örgütsel sağlık üzerinde liderlik stillerinin etkisi. Kuram ve Uygulamada Eğitim Yönetimi, 13(49), 57-91.

Lipman-Blumen, J. (2011) Toxic leadership: A Rejoinder. Representation, 47(3), 331-342, DOI: $10.1080 / 00344893.2011 .596444$.

Lubit, R. (2004) The tyranny of toxic Managers: An emotional intelligence approach to dealing with difficult personalities, Ivey Business Journal, 14-34.

O'Neill, J. (2017). The toxic university: zombie leadership, academic rock stars, and neoliberal ideology. Journal of Education Policy, 33(3), 440-44. DOI: 10.1080/02680939.2017.1418729.

Owen, H., Hodgson, V. ve Gazzard, N. (2011). Liderlik el kitabı: Etkin liderlik için eksiksiz ve pratik bir kllavuz. (3. bask1). İstanbul: Optimist

Pelletier, K. L. (2010). Leader toxicity: An empirical investigation of toxic behavior and rhetoric. Leadership, 6(4), 373-389. doi: $10.1177 / 1742715010379308$. 
Pelletier, K.L. (2012). Perceptions of and reactions to leader toxicity: Do leaderfollower relationships and identification with victim matter? The Leadership Quarterly, 23(3) 412-424.

Reyhanoğlu, M. ve Akın, Ö. (2016). Toksik liderlik örgütsel sağlığı olumsuz yönde tetikler mi? Insan ve Toplum Bilimleri Araştırmalan Dergisi, 5(3), 442-459.

Reed, G. E. (2004). Toxic leadership. Military Review, 67-71.

Mith, N. ve Fredricks-Lowman, I. (2019). Conflict in the workplace: A 10-year review of toxic leadership in higher education. International Journal of Leadership in Education. DOI: 10.1080/13603124.2019.1591512

Şentürk, C. ve Sağnak, M. (2012). İlköğretim okulu müdürlerinin liderlik davranışları ile okul iklimi arasındaki ilişki. Türk Ĕ̆itim Bilimleri Dergisi,10(1), 29-47.

Şişman, M. ve Turan, S. (2005). Eğitim ve okul yönetimi. Edt. Yüksel Özden, Eğitim ve kul yöneticiliği el kitabı içinde. Ankara: PegemA.

Uysal, O. K. (2018).Ortaokullarda örgütsel toksisitenin kaynaklarmnn, etkilerinin ve örgütsel toksisiteyle başa çıma stratejilerinin incelenmesi (Yayımlanmamış yüksek lisans tezi). Sabahattin Zaim Üniversitesi, İstanbul.

Yalçınsoy, A., ve Işık M. (2018). Toksik Liderlik ile örgütsel bağlllık ve işten ayrılma niyeti ilişkisine yönelik bir araştırma. Gaziantep University Journal of Social Sciences, 17(3), 1016-1025.

Yavaş, A. (2016). Sectoral differences in the perception of toxic leadership. Procedia - Social and Behavioral Sciences,229, 267-276.

Zagross, H. ve Jamileh, Z. (2016). Relationship between toxic leadership and job stress of knowledge workers. Studies in Business and Economics, 11(3), 8489.

\section{Kaynakça Bilgisi / Citation Information}

Tepe, N. ve Yılmaz, G.(2020).Öğretmenlerin okul iklimi algılarının yordayıcısı olarak okul yöneticilerinin toksik liderlik davranışları. OPUS-Uluslararası Toplum Araştırmaları Dergisi, 15(25),33603381.DOI: 10.26466/opus.667320 